\title{
Visual Quality Effect on Sustainability of Kampung Pelangi Semarang
}

\author{
Teti Indrawati Wuryaningsih ${ }^{1, a)}$, Bambang Setioko ${ }^{1, b)}$ and Suzanna Ratih Sari ${ }^{1, c)}$ \\ ${ }^{1}$ Architecture Department, Faculty of Engineering, Diponegoro University \\ a) Corresponding author: tetyindravati@gmail.com \\ b) keliek2000@yahoo.com \\ c) ratihsaris@yahoo.com
}

\begin{abstract}
Kampung Pelangi Semarang has relatively dense buildings, spontaneously developed and lack of urban service facilities. The design of the area based on the aspects of physical quality, one of which is the visual quality. Visual signs are the main features that are physically visible. The core of this research is to identify the influence between visual quality and sustainability in Kampung Pelangi. The research method is quantitative, weighted using Likert scale and test by using linear regression analysis. Results from simultaneous research indicate that visual quality influences on sustainability in Kampung Pelangi. The magnitude of the influence of visual quality is only $44.7 \%$ of the sustainability, the rest of $52.3 \%$ is influenced by other factors, while partially regression analysis showed no influence from three variables. It means that there is still lack of diversity, dominance and clarity at the research locus, so it needs to be increased again with values of $-3.9 \%,-2.6 \%$ and $5.8 \%$ respectively. It should be furtherly improved by adding coloring, marking and map themes, and adding various tourist attractions. For the other three variables, sequence, harmony, and uniqueness have an influence on sustainability in Kampung Pelangi, with the value of $19 \%, 17,1 \%$ and $17 \%$, that the variables already exist in research locus but the value is very low so it must maintained and upgraded with the planning and implementation of proper programs to increase the level of sustainability there.
\end{abstract}

Keywords: Kampung Pelangi Semarang, sustainability, visual quality

\section{INTRODUCTION}

Kampung Pelangi is an urban village with a complex and dynamic social system, inhabited by a variety of urban residents with generally poor economic levels, relatively dense buildings and livelihoods in the informal sector, organic developed so it lack of urban services such as roads, clean water, sanitation and drainage. Kampung Pelangi residents provide their own homes, control the environment, and work together to improve their lives. It is located at Kali Semarang river banks which create settlements around Mount Brintik.

In order to maintain the assets and the historical values of Kali Semarang area and to create a good system of building and environment, Semarang City Government has prepared The Regional Building and Environmental Management Plan (RTBL) for Semarang area. On the eastern side of Pasar Kembang (Flower Market), there are residential areas that have long occupied the area of Mount Brintik, which is the origin settlement area of Kampung Pelangi. This area has quite dense building, located on contoured land, densely populated and unorganized and it is 
clearly reducing the beauty or image of the hilly area. In order to change the image of slum into more attractive residential areas to support the revitalization program of Kali Semarang and Pasar Kembang, Government of Semarang implemented thematic village in the area with particular branding as Kampung Pelangi (Rainbow Village), by applying colorful painting on the buildings in the village of Wonosari.

The recent design of the city is based on the aspects of physical quality, one of which is the visual quality. Visual marks are the main features that are physically visible, which can contribute to the visual source in a certain visual system quality. Furthermore, it is said that visual quality is a special attribute that exists in a visual system determined by the cultural values and physical properties that can be seen from its forms, such as lines, shapes, textures, colors, scales and spaces that can form diversity, dominance, harmony, continuity, order, uniqueness and unity of a region [1].

The concept of sustainability is basically the fulfillment of the needs of today's society without neglecting the ability of future generations to meet their needs, as a process of change where resource use, investment direction, development orientation and institutional change are always in development and synergistically reinforce both present and future potential coming to meet human needs and aspirations [2].

Sustainable Tourism is expected to be implemented in Semarang's Kampung Pelangi, where tourism development and new investment in the tourism sector should not bring adverse impacts and can blend with the existing environment and can continue for long periods of time and not for a moment.

Kampung Pelangi as a pilot project of a urban village tourist destination has a very important value that must be maintained and sustained. The improvement program such as painting and improving the visual quality available in Kampung Pelangi can give influence to the success of sustainability of Kampung Pelangi Semarang.

Temporary assumption of visual changing in painting and the addition of visual elements was aimed to improve the quality of the area. The final goal is becoming the village as tourist destinations in Semarang City which expected to be the factors that support Kampung Pelangi as a sustainable tourism village. The research is done to know whether there is influence of the visual quality on the sustainability of Kampung Pelangi Semarang.

\section{Visual Quality}

According to [1] quality is the level of excellence, superior in form, distinguishing attributes. Visual means can be seen by the sense of sight (eye), while Visual Understanding according to [1]. Visual signs are the main physical features can be seen, which can provide attributes to the visual source and a visual system, so the visual system has a certain quality. It is further said that the visual quality is a special attribute that exists in the visual system that is determined by the cultural values and the physical property.

Visual signs are the main features that are physically visible that can attribute to the visual source in a visual system so that the visual system has a certain quality. The visual value of a region is indicated by the physical quality formed by the relationship or interrelation between the visual elements in a city landscape [1]. Attributes that can show the visual quality in an area include [1]:

- Diversity is a collection of various pattern and arrangement elements.

- Domination is something that is part of two different parts, one of which dominates the other and becomes one of the elements that is visually highlighted and the other becomes the background.

- Harmony is Display of all different parts into one unit. Representation of all opposing elements (in works of art) to be a pleasant unity.

- Sequences are units arranged sequentially from one unit to another with a certain pattern.

- Uniqueness is a rare or unusual source of visual, visual character, or visual quality found on a regional or national scale.

- Sharpness/vividness is an impressive visual appearance, which is formed by interesting or visually interesting elements or units.

\section{Sustainability}

According to the Brutland Report at the UN session in 1987, sustainable development is a principled development process to meet current needs without sacrificing the needs of future generations. While sustainable cities are cities that allow all citizens to meet their needs and improve their welfare, without degrading the condition of the natural environment or the lives of others, in the present and in the future [3] 
The concept of sustainability is a simple concept, but complex, so the understanding of sustainability is very multidimensional and multi interpretation, but the most prominent and used by many people is sustainable development that carries three dimensions, there are economic, social and environmental, though carrying the same dimensions, about the form of linkage between the three dimensions [4], see figure 1.

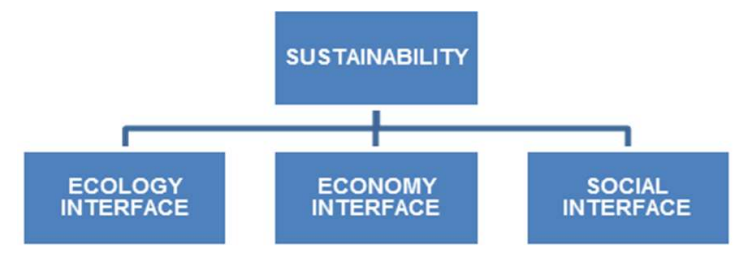

FIGURE 1. The balance in three pillars of Sustainability [4].

\section{METHODOLOGY}

The steps in this study is to determine the theory relating to the topic taken and then test it. Go directly to the study field by reviewing directly and conducting a comparative study. Then make a comparison of area activities. Difficulty during the data collection is the difference of perception and meaning on the individual in describing the topic. The method is quantitative research method. This method can overcome the verbal descriptions of the environment. In this method, we can obtain response from some/ sampling which then accumulated in data collection and then analyzed. The quantitative method is based on regression testing. Variable causality is differentiated into dependent variable (affected variable) and independent (influence variable). The independent variable or influence variable in this research is visual quality based on Grand Theory used [1] which analyzed through indicator of diversity, dominance, harmony, sequence, uniqueness and vividness. While dependent variable or affected variable in this research is Sustainability of Kampung Pelangi Semarang which seen from three main dimension, ecology, economic, and social, see Figure 2.

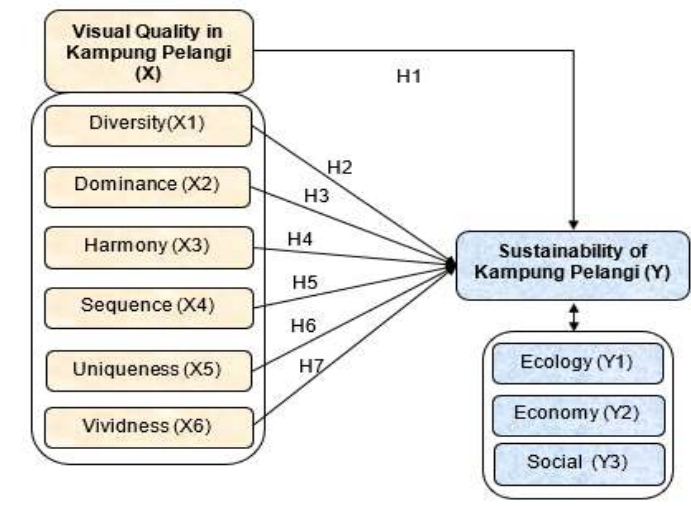

FIGURE 2. Correlation and hypothesis influence of independent variables to dependent variable.

Visual value in an area is indicated by physical quality formed by a relationship or interrelation between visual elements on one city landscape. With the assessment criteria as the following [1]:

- Diversity, Collection of various pattern elements as well varied arrangement.

- Dominance, One of two different parts must be clearly dominates the others.

- Harmony, Display of all the different parts of grouping.

- Intactness, Continuity of views and meaning wide is free from obstruction of view.

- Sequence, The units are arranged in order from one unit to another unit with certain patterns. 
- Uniqueness, Visual sources, visual characters, or rare quality or unusual visuals found on a regional or national scale.

- Unity, Harmony in all views, suitability between landscape elements.

Data collection methods are divided on how to obtain:

1. Observation. The goal is to know the actual condition of the region about the potential and weaknesses of the region.

2. Questionnaire

3. Secondary Data

According to [5], a simple linear regression analysis or single regression analysis is an analytical technique that seeks a functional relationship between one dependent variable and one independent variable. Before performing regression test, normality test is performed to find out the variables and sought functional relationship so that it has normal distributed data, so that the data show can be normally distributed then the data can be used in regression analysis to find the influence between the independent variable to the dependent variable. The next step is the technique of explanation.

According to [6], data analysis with statistics only shows data that has been read and has methodological meanings and explanations but has not entered the substance of the research. Therefore, researchers are required to know the real conditions. The researcher is given the opportunity to express his thoughts, ideas which he thinks are right based on what he believes, which he experiences during research and based on what he learned from previous theories.

\section{RESULTS AND DISCUSSION}

Kampung Pelangi is located in the village of Wonosari, Randusari Sub District, South Semarang District, Semarang City. Located in downtown of Semarang near Tugu Muda CBD. Kampung Pelangi is a residential area located on a hilly area known as Mount Brintik ( figure 3).

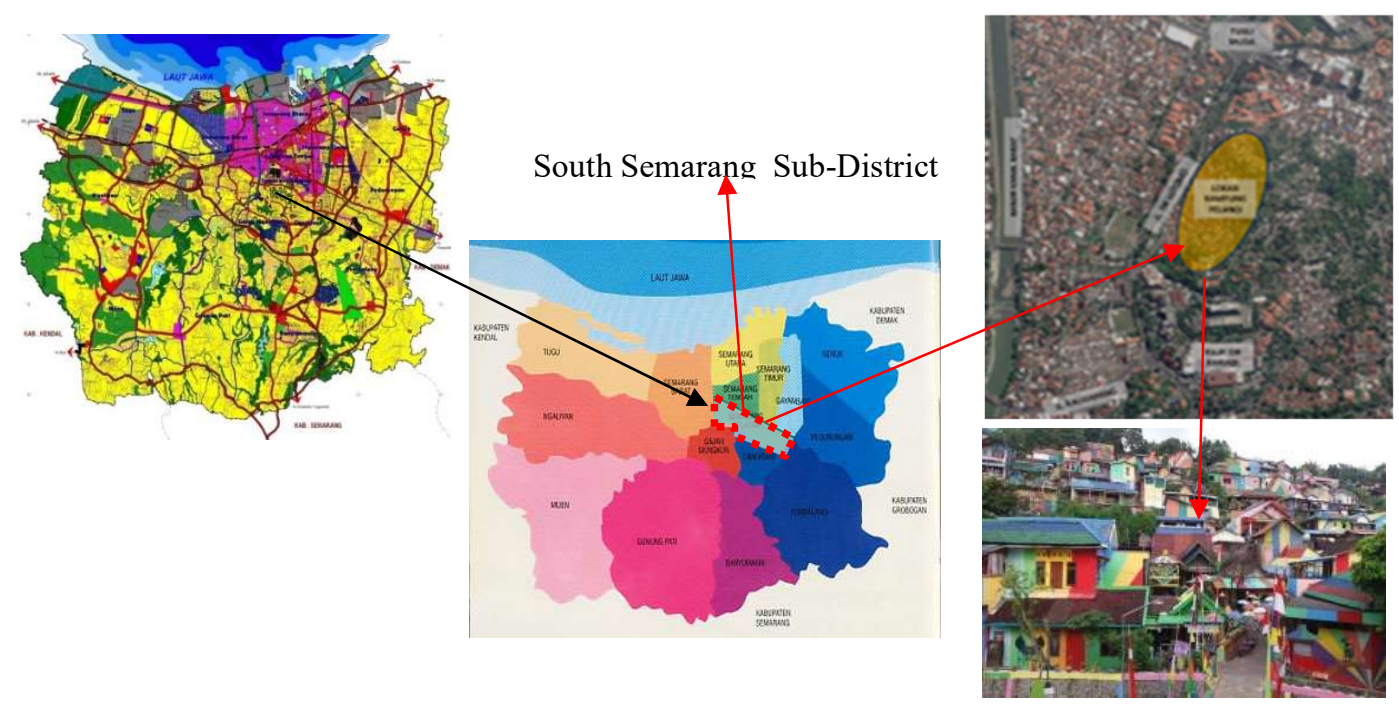

FIGURE 3. The location of the research

\section{Coefficient of Determination}

Coefficient determination analysis in multiple linear regressions was performed to know the percentage of contribution of independent variable influence (Visual Quality) simultaneously to the dependent variable (Sustainability). Table 1 shows the adjusted $R$ Square $\left(R^{2}\right)$ is 0.477 . It means $47.7 \%$ variation on Sustainability can 
be explained by the variation of six independent variables namely diversity, dominance, harmony, sequence, uniqueness and vividness. $52.3 \%$ variation on Sustainability can be explained by other variables outside the model. According to [7], the degree of influence of visual quality on sustainability in Kampung Pelangi is in Medium category $(0.40-0.599)$.

TABLE 1. Coefficient Determination Test Results

\begin{tabular}{lrrrr}
\hline Model & R & R square & $\begin{array}{c}\text { Adjusted r } \\
\text { square }\end{array}$ & \multicolumn{1}{c}{ Std. Error of the estimate } \\
\hline $\mathbf{1}$ & $.713^{\mathrm{a}}$ & .509 & .477 & .262085322018299 \\
\hline
\end{tabular}

\section{Anova Test / F Test}

Anova test is a multiple linear regression test or an independent variable (Visual Quality) simultaneously with the dependent variable (Sustainability), and the result is as follows:

TABLE 2. Anova test results

\begin{tabular}{|c|c|c|c|c|c|c|}
\hline \multicolumn{2}{|r|}{ Model } & Sum of Squares & $\mathrm{df}$ & Mean Square & $\mathrm{F}$ & Sig. \\
\hline 1 & Regression & 6.612 & 6 & 1.102 & 16.044 & $.000^{\mathrm{a}}$ \\
\hline & Residual & 6.388 & 93 & .069 & & \\
\hline & Total & 13.000 & 99 & & & \\
\hline
\end{tabular}

a. Predictors: (Constant), Diversity, Dominance, Harmony, Sequence, Uniqeness, Vividness

b. Dependent Variable: Sustainability

Table 2 above shows that the sig value. is 0.000 which means less than 0.05 . It indicates that there is influence on the Visual Quality with variables of diversity, domination, harmony, sequence, uniqueness and vividness simultaneously on the sustainability of Kampung Pelangi Semarang. F $=16.044$ means that there is a linear relationship between visual quality and rainbow sustainability, and $\mathrm{F}=16.044$ is bigger than $\mathrm{F}$ table $=2,31$ means $\mathrm{H} 0$ is rejected and $\mathrm{H} 1$ accepted.

Hypothesis H0 : There is no effect of Visual Quality on Sustainability in Kampung Pelangi Semarang (Rejected) Hypothesis H1: There is an effect of Visual Quality on Sustainability in Kampung Pelangi Semarang (Accepted)

\section{Multiple Linear Regression Test / $t_{\text {test }}$}

$\mathrm{T}$ test is known as the partial test, to test how the influence of each independent variable individually to the dependent variable. This test can be done by comparing $t_{\text {stat }}$ with $t_{\text {table }}$ or by looking at the column of significance on each $t_{\text {stat }}$; the $t_{\text {test }}$ process is identical with $\mathrm{F}$ test [5].

The results of multiple linear regression test above can be understood with the following mathematical equations and can be seen with the Bungin diagram in table 3, as follows:

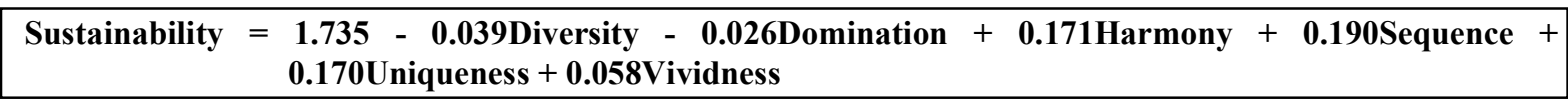


TABLE 3. $t_{\text {test }}$ Result

\begin{tabular}{lccccc}
\hline \multicolumn{1}{c}{ Model } & \multicolumn{2}{c}{ Coefficients a } \\
& $\begin{array}{l}\text { Unstandardized } \\
\text { Coefficients } \\
\text { B }\end{array}$ & $\begin{array}{c}\text { Std. } \\
\text { Error }\end{array}$ & $\begin{array}{c}\text { Standardized } \\
\text { Coefficients } \\
\text { Beta }\end{array}$ & t & Sig. \\
(Constant) & 1.735 & 0.322 & & & \\
Diversity & -0.039 & 0.083 & -0.042 & -0.467 & 0.642 \\
Domination & -0.026 & 0.083 & -0.031 & -0.317 & 0.752 \\
Harmony & 0.171 & 0.065 & 0.276 & 2.627 & 0.01 \\
Sequence & 0.190 & 0.072 & 0.295 & 2.619 & 0.01 \\
Uniqueness & 0.170 & 0.083 & 0.236 & 2.057 & 0.042 \\
Vividness & 0.058 & 0.077 & 0.074 & 0.75 & 0.455 \\
a) Dependent variable : Sustainability & & & \\
\hline
\end{tabular}

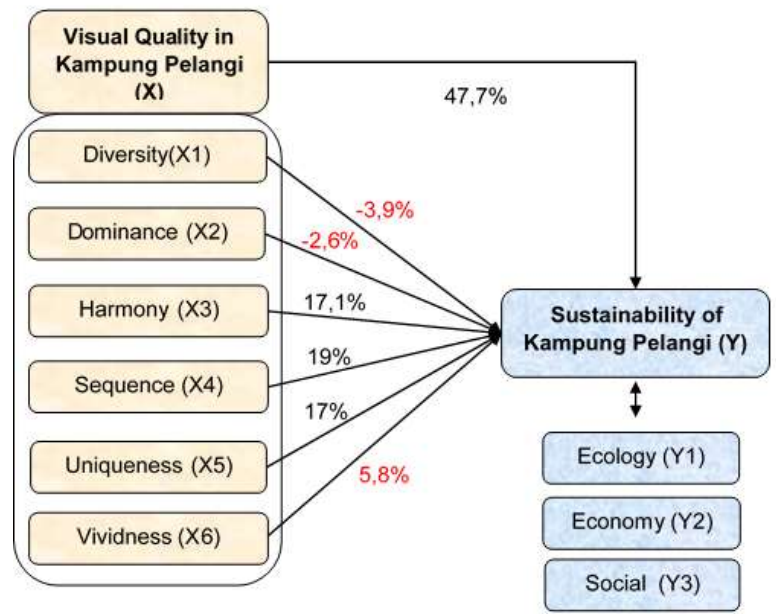

FIGURE 4. Results of multiple linear regression / $t$ test with Bungin diagram model

There are three variables that influence the sequence, harmony and uniqueness with low value are $19 \%$, $17,1 \%$ and $17 \%$, respectively. Three unaffected variables which can be interpreted that the research locus value is so low that it must be increased, such as diversity, dominance and vividness, with values of $-3.9 \%,-2.6 \%$ and $5.8 \%$ respectively, see the relationship in figure 4.

Sequences variable in Kampung Pelangi is available, effecting the sustainability there, but has a low value of $19 \%$. It means to be maintained and enhanced by the addition of new and more interesting photo spots / sequences, see figure 5 .

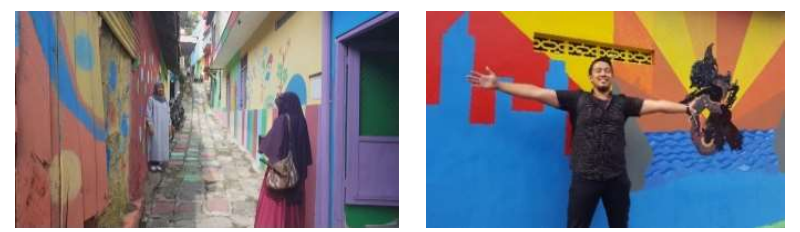

Existing Sequence

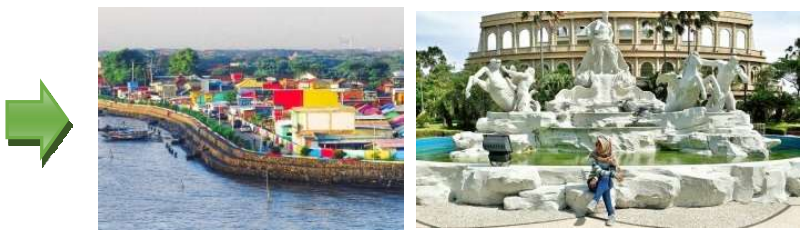

Sugestion

FIGURE 5. Sequence in Kampung pelangi is available but quantity and quality are less, therefore effecting sustainability in Kampung Pelangi with low value, therefore should get correct improvement. The addition of a unique sclupture to take pictures and revitalize the river elements to get an interesting view.

Harmony variable in Kampung Pelangi has existed, affecting the sustainability with a low value of $17.1 \%$. It reflected the harmony of the building with the environment in the form of contoured soil by not using cut and fill 
process, the harmony of color composition and texture. The increase of this element will increase the value of sustainability as well, with the addition of green open spaces to the public, the addition of gazebo to communal spaces, the arrangement of tourist routes to be more harmonious etc., see figure 6 .
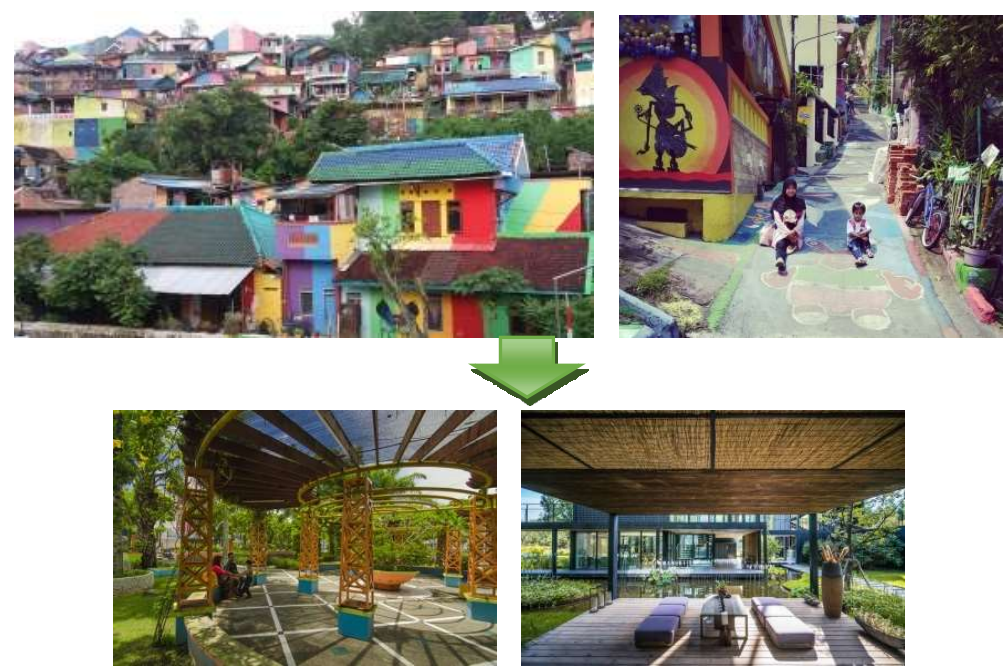

FIGURE 6. Existing harmony is shown in Kampung pelangi (above). Suggestion is by additing of vegetation, communal space and tents to promote harmony in the rainbow village (below)

Uniqueness variable in Kampung Pelangi has existed, affecting the sustainability of Kampung Pelangi with a low value of $17 \%$, shown in the unique steps, the unique colorful rainbow painting, and the existence of Kasmaran Park that supports Kampung Pelangi as an interesting spot to enjoy the area from a distance. The value of uniqueness can be increased by adding visual values such as architectural elements, typical furniture of Semarang, the typical building of Semarang and the addition of Semarang culinary stalls, see figure 7 and 8.
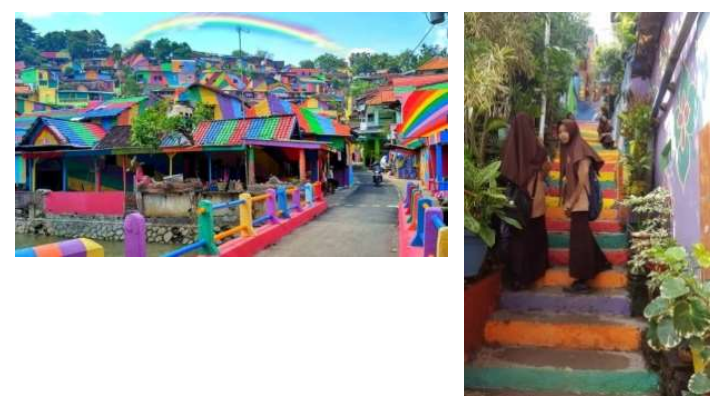

Existing Uniqueness
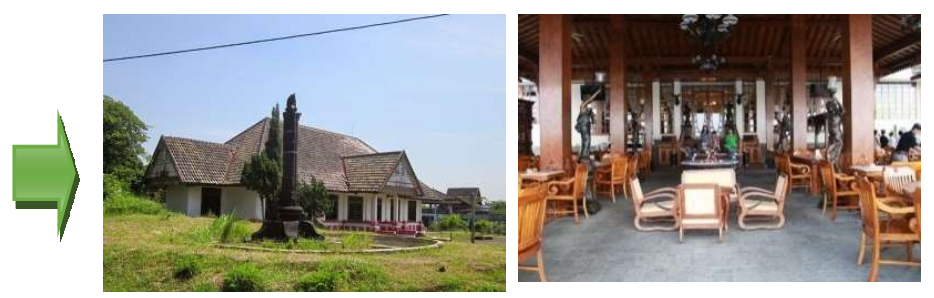

Sugestion

FIGURE 2. Uniqueness is indicated by the unique steps, unique colorful rainbow paint view and the existence of Kasmaran Park.

Variables of diversity, dominance and vividness in the Kampung Pelangi has not available. This is indicated by the result of linear regression analysis showing that the three factors show negative and low value with each value are- $3,9 \%,-2,6 \%$ and $5,8 \%$. These three factors become homework for all of us to raise the value in order to achieve the desired sustainability. Ways to increase it include the addition of diversity by providing a clear theme or color concept, or zone provision and arrangement of specific mural images, the addition of tourist attractions such as boat tours and fishing, and children's playground and the addition of culinary booths Semarang with diverse formation. Domination can be added by the liberation of the view from the Sutomo Street which is blocked by the display of 
the flower market which is actually the entrance of Kampung Pelangi. The gate should be bigger and dominate the corridor. Vividness can be increased by adding the signage and tourist maps and optimization of the Kasmaran Park, see figure 8 and 9 .
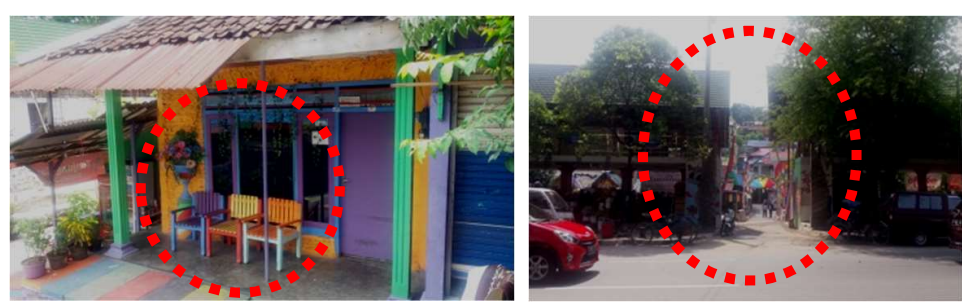

FIGURE 8. Lack of street furniture (left) and invisible entrance gate (right)
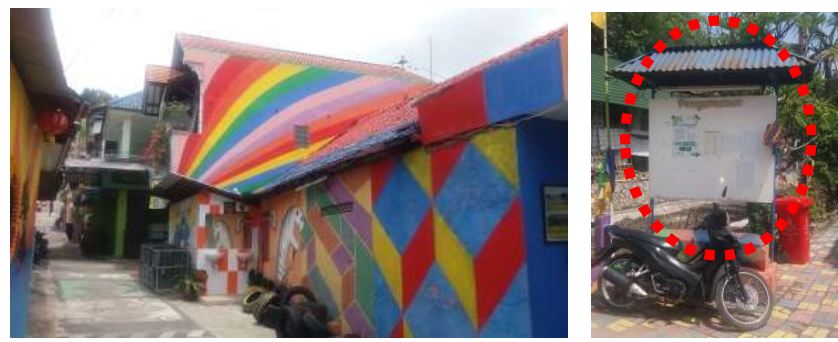

FIGURE 9. Too colorful makes boring (left) and lack of signage and tourist maps (right)

In the World Commission on Environmental Development (WCED) states that sustainable development is a development that seeks to meet the needs of today without reducing the ability of future generations to meet their needs; in this case sustainability is defined as the ability to survive as a tourism village [8]. The shape and mass of the Kampung Pelangi is quite ordinary or lack of art and beauty. Circulation and parking in the area lacks of good pattern because the visitors motorcycle can enter in the pockets of the road inside the Kampung Pelangi or on the sidewalk in front of the flower market. Kampung Pelangi has an inadequate green open space and Kasmaran Park as a supporting park is located too far from the entrance. The pedestrian area do not function properly because it is used by road bikers. Signage and directions mark in the Kampung Pelangi as a tourist village is less. Supporting activities such as souvenir shops, good informal sector arrangement and children playground in the Kampung Pelangi are still relatively less.

\section{CONCLUSION}

Visual quality in Kampung Pelangi has an influence on sustainability of Kampung Pelangi at 47,7\%, the rest of $52,3 \%$ is influenced by other factors outside the research locus. This means that physical influence has not fully affected sustainability in Kampung Pelangi Semarang so it needs to be increased simultaneously in all variables. While partially there are three factors that influence the sequence with the percentage of $19 \%$, Harmony $17,1 \%$ and the uniqueness $17 \%$, while the other three variables have not shown a positive value. It can be interpreted that variables diversity, dominance and clarity with value respectively $-3,9 \%,-2,6 \%$ and $5,8 \%$ at research locus are very low.

Hence, it needed program and hard work of government supported by private and the villagers of Kampung Pelangi mainly in the variables with the lowest values such as diversity, dominance and clarity, while for the three other variables that influence the value which is also minimal / low i.e. sequence, harmony and uniqueness also need to be maintained further and improved its value. The following recommendations are:

- The addition of attractions and recreation are appealing to visitors

- Increase the quality of accessibility in Kampung Pelangi

- Arrange style and style of architecture to match the existing settlements 
- Solid waste management and waste recycling system so that the waste generated can be processed again into new goods with more value, optimization of Semarang by keeping clean, even upgraded to the attraction for visitors in the form of riverfront attraction, where the center of the eye can be fixed on the river as the village node rainbow with the provision of tourist boats that can be mounted with a levy that is not too expensive to attract visitors and more open employment opportunities for local residents

- Plan a Government program that supported by Corporate Social Responsibility and community participation related to increasing sequences such as the addition of photo spots and other visual elements, harmony in the form of coloring themes and align coloring in the Kampung Pelangi, as well as the uniqueness of making events and attractions in Kampung Pelangi or Kasmaran Park so as to increase public interest to visit while improving local culture.

- Providing socialization of the importance of maintaining the environment by providing sufficient green open space, not only filled with house building. Every home should have a garden for greening and beautify the visual of the house and using local ecological materials.

\section{REFERENCES}

[1] Smardon, Richard, “Foundation for Visual, Project Analysis”, New York: John Wiley \& Son,1986.

[2] Budiharjo, E dan Sujanto, D., "Kota Berkelanjutan”, Bandung:PT. Alumni,2005.

[3] Girardet, H., "Cities People Planet: Liveable Cities for a Sustainable City", Aldershot: Ashgate Publishing Ltd,2004.

[4] Lachman, Beth E., "Lingking Sustainable Community activities to pollution prevention : A sourcebook", RAND, 1997.

[5] Ghozali, Imam, "Aplikasi Analisis Multivariate dengan Program IBM SPSS 23", Semarang: Badan Penerbit Universitas Diponegoro,2016.

[6] Bungin, B.,"Metode Penelitian Kuantitatif: Komunikasi Ekonomi dan Kebijakan Publik Serta Ilmu-ilmu Sosial Lainnya”, Jakarta: Gramedia Pustaka, 2005.

[7] Sugiyono, S.,"Metode Penelitian Kualitatif. Bandung”,Bandung: CV. Alfabeta,2009.

[8] WCED, "Our Common Future (The Brundtland Report)", Oxford: Oxford University Press, 1987 